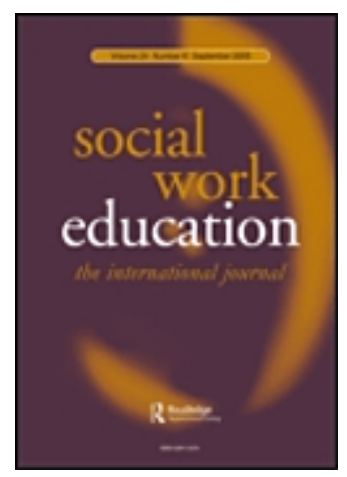

\title{
Innovating Adult Social Work Practice - Learning from the Named Social Worker for Adults with Learning Disabilities Pilots
}

\begin{tabular}{|r|l|}
\hline Journal: & Social Work Education \\
\hline Manuscript ID & CSWE-2018-0005.R1 \\
\hline Manuscript Type: & Article \\
\hline Keywords - free form: & $\begin{array}{l}\text { adult social care, risk, human rights, threshold concepts, } \\
\text { deinstitutionalisation }\end{array}$ \\
\hline Keywords: & $\begin{array}{l}\text { Learning disability < Practice, Post Qualifying < Education, Adult care < } \\
\text { Practice, Social justice < Values, Disablism < Values }\end{array}$ \\
\hline
\end{tabular}

\section{SCHOLARONE \\ Manuscripts}




\title{
Innovating Adult Social Work Practice - Learning from the Named Social Worker for Adults with Learning Disabilities Pilots
}

\author{
Elaine James, Hannah Morgan and Rob Mitchell \\ Elaine James, Centre for Disability Research, Division of Health Research, Lancaster \\ University
}

ORCID 0000-0002-3133-5298 e.james4@lancaster.ac.uk

Hannah Morgan Centre for Disability Research, Department of Sociology, Lancaster University

ORCID 0000-0003-1039-9337ｈ.morgan@lancaster.ac.uk

Rob Mitchell, Centre for Disability Research, Department of Sociology, Lancaster University and City of Bradford Metropolitan District Council, Bradford

ORCID 0000-0002-2391-4513＜compat>ㅡㅁ.mitchell@bradford.gov.uk

Correspondence to e.james4@lancaster.ac.uk

\section{Acknowledgements}

The authors wish to thank Professor Chris Hatton for his advice and support throughout the pilot and to Nina, Shvonne, Ryan, lan, Jack, and Mark who piloted the role of named social worker. We also wish to thank Emma Palmer for her kind comments on an earlier draft of this paper. Finally, we want to give particular thanks to Bradford Talking Media, Cumbria People First, Lead the Way and People First Bradford for their challenge, insight and contribution as experts by experience to the development of the named social worker pilot. 


\begin{abstract}
In 2016, following the publication of the Vision for adult social work in England (DH 2016), the Chief Social Worker for Adults at the Department of Health in England announced the intention to pilot a new social work role - that being a Named Social Worker supporting people with learning disabilities. Phase 1 of the pilot has tested a reframing of the social work role as a relational practitioner with an expertise in human rights, freed from transacting the management of care. Phase 2 is now underway testing key knowledge and skills requirements for post qualifying practice in the field of social work supporting adults with learning disabilities. Heuristic approaches are capturing outcomes from generative learning processes throughout the pilot. The insight emerging from this national pilot is that at its heart, named social work is about qualifying and on-going postqualifying social work education which promotes and maintains practitioner reflexivity and connection to their social work values. We are finding that selfadvocates may be a critical influencing factor, positively affecting the sources of resistance through making explicit the connection between social work values and lived experience of practice from the people social workers are there to serve.
\end{abstract}

Keywords: social work; adult social care; learning disability; risk; human rights; intellectual disability; deinstitutionalisation; professional practice; threshold concepts 
Introduction

In response to the No Voice Unheard, No Right Ignored consultation (DH 2015), the Department of Health in England announced in 2016 that it would be piloting the role of a Named Social Worker to support people with learning disabilities. It invited applications from local authorities wanting to test innovative ways of practice that would 'provide a clear picture of social work practice and service design in this crucial are' (DH 2016:7). The Chief Social Worker for Adults in England, Lyn Romeo, described the pilot as an opportunity to build on the 'established values, knowledge, skills and ethics of social work', those being 'holistic, person-centred and proactive in co-opting awareness and support from other services' to ensure people's dignity is respected and their rights are upheld (Romeo, 2016). The pilot included testing of the role of a Named Social Worker as a dedicated caseworker, as being the main points of contact for people and their families, and as providing a professional voice which challenged and advocated for people across the system.

Six local authority areas in England were funded by the Department of Health to pilot the role of a Named Social Worker working to support adults with learning disabilities during phase 1 which ran from October 2016 to March 2017. Phase 1 of the pilot was extended for a further period through until August 2017. Three of the phase 1 Local Authorities continued into phase 2, working alongside three new local authorities, which ran from October 2017 to March 2018. The final report was published in July 2018 concluding that people with learning disabilities feel more supported and involved in shaping their plans and support for the future when they have access to a named worker (Romeo, 2018) whose approach was 
both relational in approach and focused on advocacy for the person within holistic person-centred planning for care and support (SCIE 2018).

Our involvement as the Centre for Disability Research (CeDR) ${ }^{1}$, has been to support two of the sites across both phases of the pilot. CeDR was commissioned by Local Authority 1 and Local Authority 2 as a service evaluation (ESRC, 2015), providing academic challenge, rigour, ethical and moral guidance (JUC, 2016) to the pilot activities. The research centre provided advice on evaluation through participatory research in action approaches led by practitioners. Such approaches aim to integrate the iterative process of knowledge and insight generation with generation of specific recommendations to improve practice which are then integrated into the continuous cycle of learning (Shaw, Lunt \& Mitchell 2014). The critical nature of participatory research in action research traditions was determined to be relevant to the named social work pilot as it resonated with social work critically reflective action learning cultural conventions (Kemmis 2008). This was through furthering our examination of the potential for disability studies founded on the social model of disability to act as the threshold concept (Meyer and Land 2003) through which transformative insights can be generated into, and impact on, social work education and practice (Morgan 2012). By nature, exploration of threshold concepts results in generative learning which is 'troublesome' because it involves engaging with knowledge that can be experienced as ' 'alien', counter-intuitive or even intellectually absurd at face value' (Meyer and Land 2003:2). It can therefore signal the need for ontological

\footnotetext{
${ }^{1}$ Hannah Morgan is Director of the Centre for Disability Research (CeDR) at Lancaster University. Elaine James and Rob Mitchell are honorary members of staff at Lancaster University as well as members of the senior leadership team in pilot site 1 and subsequently in pilot site 2 which they moved to at the end of phase 1 of the pilot.
} 
shifts (Cousin 2006) which challenge the value base of historical practice in the field. This can result in turbulent times for practitioners as they seek to integrate the new insight about the impact of their practice on people with learning disabilities' lives with their social work identity and values base.

This can be particularly troublesome for practitioners who genuinely felt this historic practice was routed in social work values and producing acceptable outcomes for people with learning disabilities (James and Mitchell 2017). The development of user-led organisations and aligned academic work that privileged the voices of disabled people and others who use services identified differences in the ways in which disabled people and professionals conceptualised and applied values and approaches. This has been particularly stark in relation independence, because as Oliver noted in The Politics of Disablement in advancing the idea of independence, professionals and disabled people have not been talking about the same thing' (1990:91). While Oliver acknowledged that there had been attempts (by the late 1980s) to address this, his firm conclusion was that "power and control continue to remain with professional staff' which traps disabled people and professionals in dependency-creating relationships (1990:90). Writing more recently Beresford and Boxall highlight the ways in which 'even the strong, articulate' individual and collective voices of users/survivors of social work services continue to have a 'limited impact on social work practice' (2012:165). They argue that the requirements for the involvement of service users in social work education introduced by the Department of Health (2002) and strengthen by the revised Standards for Education and Training produced by the Health and Care Professions Council (HCPC, 2017), the current regulator for social work in England), are insufficient without the involvement of service users in 'determining the 
underpinning knowledge for social work practice' This requires collective involvement of disabled people through user-led organisations (ULOs) to support ‘disabled people's consciousness raising and capacity to achieve social change' and to contribute to the extension of knowledge for social work education and practice (2012:164).

Through our involvement in the pilot we are examining how self-advocates may provide authentic unmediated voices which connect and resonate with social work values and act as an encouraging and enabling factor in effecting transition into a new model of practice.

The purpose of this paper is to share the initial insights being generated from our participation in the pilot and invite wider debate on their implications for qualifying social work education and post-qualifying continued professional development focused particularly on cooperative design and delivery of social work education in partnership with people who have lived experience of social work interventions.

\section{Genealogy of the Named Social Worker Role in Adult Social Work Education}

The named social worker pilot follows on from earlier attempts to reform adult social work practice. Fifteen years earlier the Strategic Learning and Research Advisory Group for Health and Social Care (StLaR 2002/2003) argued for the need for professional reform to reframe social work practice with adults through:

- strengthening the intellectual nature of the profession;

- building on advancement through progressive expertise and research excellence; 
- developing model careers which reduce levels of variation of professional practice between employers to reflect that social work is a national profession with practitioner mobility between employers.

This earlier attempt at reform, was perhaps frustrated through its own design, it was conceived as an internally focused debate between professionals. As Beresford and Croft (2004) observed, if social work practice is to regain an emancipatory focus freed from transactional concerns of care management, a much closer alignment is required between social workers and people who experience social work practice and user-led self-advocacy organisations and movements.

The National Social Work Reform Board (DH 2010) constituted in 2009, was given the remit to review the whole social work profession in an effort to better determine and define what good social work looked like, how it was experienced by others and crucially what the implications would be for the future professional development of social workers. The Reform Board provided an arguably more inclusive environment in that it included representatives from people using services and carers in addition to inter-professional debate between social work agencies, social work employers and practice educators. The Reform Board recommendations, which were subsequently adopted by The College of Social Work (TCSW 2012) and endorsed by Health and Care Profession Council (HCPC), challenged the profession and outlined an approach towards developing social work practice which would be more accountable to the adults who social workers were there to serve (Bogg 2008). A summit organised by The College of Social Work called for the social work profession, particularly in adult social work, to be 
'liberated from the care management straight jacket so as to be able to be creative and focussed on problem solving in its approach to supporting users and carers' (TCSW 2012 p.4).

The internal dialogue within the profession about its role and purpose, has run in parallel to the growing confidence on the part of people who experience social work and user-led organisations in describing what they would define as better social work. Drawing on a large-scale qualitative study with users of palliative care services Beresford et al (2007) highlight the importance of emphasising relational approaches between the person and their social worker, qualities and skills which highlight notions of 'friendship' and human qualities such as warmth, empathy, respect and listening. Similarly a literature informed discussion paper produced by the national servicer user organisation Shaping Our Lives for The Changing Roles and Tasks of Social Work review stated service users particularly value relationships with social workers underpinned by 'positive personal qualities.. [which] include warmth, respect, being non-judgemental, listening, treating people with equality, being trustworthy, openness and honesty, reliability and communicating well' alongside practice which is

'participatory...offers continuity, is flexible and person-centred, is holistic and social model based, connects the personal with the social and political, offering personal/emotional and practical support, addresses rights, risks and their complex interrelations, [and] which is based on inclusive understandings of knowledge which includes the experiential knowledge of service users and the practice knowledge of face to face workers' (Beresford, 2007:6). 
Theses themes of humanity and being person-centred as policy priorities for social work support to people with learning disabilities have been highlighted within policy documents produced by the UK government since the 1970s. As early as 1971 the Better Services White Paper (DH 1971) called for a named professional, such as a social worker, as having potential to improve the quality of life and outcomes experienced by people with learning disabilities.

'Another (not necessarily alternative) suggestion which is being considered in some places is to nominate a 'named person' for every mentally handicapped person to provide a single point of contact for his family, to act as a source of advice and to ensure access to other agencies and services. Such a person may be a Social Worker or a Community Mental Handicap Nurse or could come from one of the other agencies in contact with the family' (DH 1971 Para 2.15) ${ }^{2}$

The white paper deliberately used the terminology of 'home' convey a sense of an ordinary life like any other person. The white paper also acknowledged the importance of long-lasting personal relationships for people with learning disabilities and encouraged social workers to work with families and individuals to foster closer links and lasting attachments.

The notion of the named worker role re-emerged thirty years later in UK policy documents, Valuing People (DH 2001) and Valuing People Now (DH 2007). The Valuing People agenda called for adults with learning disabilities to experience

\footnotetext{
${ }^{2}$ We acknowledge the outdated and medicalising terminology here. 'Mental handicap' was commonly used in policy and practice in the 1970s.
} 
greater choice and control over their lives through self-directed, personalised support planning. The subsequent Valuing People Now consultation further expanded self-directed support options by introducing the idea of individual budgets, whereby a person knows and has control over the budget allocated to meeting their care and support needs. For the social work profession, the impact of the policy was a furthering of what Lymbery (1998) posits as a shift away from the values of the profession towards the managerial concerns of transacting people at pace through care management, which had been introduced by the community care reforms of the 1990s. Central to achievement of the Valuing People policy intent was the idea that the person is the expert of their own life, and that whilst social workers are experts of their profession, they and may not be the best placed person to broker impactful support which would lead to better lives for adults with learning disabilities.

The subsequent reaction from the profession can, we argue, be observed in the dialogic move towards reframing of risk as a central organising principle of the professional social work role (Warner \& Sharland 2010) which is at odds with a professional role 'based on challenging the broader barriers they [users of services] face and safeguarding and advancing their rights and needs' identified by Shaping Our Lives (Beresford 2007 p5) The struggle for dialogic dominance of the purpose of social work and the continuing need for the professional role increasingly centred around stories illustrating high profile risks which resulted in people coming to significant harm (Broadhurst et al 2010). National high profile serious cases with tragic consequences for adults with learning disabilities and/or autism, such as Steven Neary (London Borough of Hillingdon v Neary and Anon2011), the residents of Winterbourne View (Flynn 2012) and the death of Connor Sparrowhawk 
(NHS Southern Health 2016; Ryan 2017) have resulted in amplification of calls to review the role of the social work profession in response to the increasingly complex environment within which it operates (Adams et al 2009; Harvey 2014). The impact of these stories of trauma, has been an increasingly sense that adults with learning disabilities receiving services are being systematically dehumanised and their rights abuse by health and social care practices which prioritises routinised processing of care management over relational practices (Goodley and Runswick-Cole 2014). In the 1980s Lipsky (1980) observed the dehumanising effect of interactions between people becoming routinsied. More recently Hatton (2015), drawing on Graeber's (2015) critique of bureaucracy to comment on the Justice for LB campaign ${ }^{3}$, highlights the structural violence inherent within health and social care characterised by 'shoddy, rigged, inhuman structures' which deny the shared humanity of people with learning disabilities.

Manthrope et al (2009) observed that without sufficient attention being applied to and within social work education arising from the introduction of mass process changes within social work practice, the extent to which adults who experience social work are supported to achieve social justice would continue to be compromised. This protracted debate continues to be explored through the named social worker pilot through discussions as to whether the purpose of pre- and postqualifying social work education is to skill social workers as operators within highly regulated settings or if it is to develop a wider repertoire of transferable skills and understanding (Moriarty \& Manthorpe 2013) with an explicit commitment to

\footnotetext{
${ }^{3}$ LB is Connor Sparrowhawk, aka 'Laughing Boy', who died a preventable death while in the 'care' of Southern Health NHS Trust in 2013. http://justiceforlb.org
} 
upholding human rights and promoting social justice (Fenton 2016; BASW and Shaping Our Lives 2016).

\section{The Named Social Worker Pilot}

Six local authorities in England were selected to be involved in the first phase of the pilot through an expression of interest process by the Department of Health. The sites were Calderdale, Camden, Hertfordshire, Liverpool, Nottingham and Sheffield. From the outset, the Department of Health determined that the Named Social Worker role should be locally defined by each site which meant that the pilot covered a variety of contexts within which people with learning disabilities were supported by social workers from community learning disabilities integrated teams, dedicated teams contributing to care and treatment reviews of people with learning disabilities at risk of Assessment and Treatment Unit (ATU) admissions, social work support for discharge from ATU and support for young people with learning disabilities who are in transition from children's into adult services. To provide an overarching baseline assessment across all sites, the following questions were put to the six sites participating in phase 1 of the pilot (SCIE 2016):

- What is the balance between the Named Social Worker enabling and supporting an individual and not creating dependency?

- How might Named Social Workers change outcomes for people without changing the fundamental structures of the system?

- What influence might Named Social Workers have on the system they were operating within? Was managerial 'permission' enough to achieve this? 
- Are social workers contributing to, or exterior to, the problems in the system they are trying to shift? In what ways could Named Social Worker teams themselves shift the way they responded to risk?

- How will we know what the impact was that a Named Social Worker has on the lives of individuals and carers?

- How could social work education and reflective practice contribute towards continuous improvement to practice on the basis of its continuous evaluation?

Supported by the Innovation Unit in partnership with SCIE (Social Care Institute for Excellence), data was captured from each site on a standardised template at three time points, the beginning, the mid-point and final stage of phase 1 . Three workshops were held with teams of up to 6 social workers and managers who were involved in the pilots from each of the six sites to undertake collective sense making of content submitted by each individual site. High level thematic coding was undertaken during each workshop to identify insights and coproduce a set of shared emerging themes which were common across the six pilot sites (Gray 2004).

\section{Findings from the Phase 1 six pilot sites}

Interim learning outcomes were captured six months into phase 1 of the pilot which attempted to describe an emerging vision for the Named Social Work role as defined by its local context within the pilot site (SCIE 2017a). At the interim learning stage, the sites reported a range of models of practice emerging. These ranged from testing an advanced form of reviewing officer through to sites which were reframing their understanding of the role through coproducing, in partnership with people with learning disabilities, a model of relational practice testing how to 
meaningfully achieve a shift in power and control, constructed from respect for individuals' human rights.

The final workshop session with the phase 1 pilot sites was held at the end of the phase 1 pilot (SCIE 2017b). Amongst the more troublesome findings from phase 1 of the pilot and being further explored during phase 2 , is the observation by the sites we are supporting that at its heart the pilot is about 'better' or 'good' social work for all adults, which would underpin a more specialised role, potentially that of Advanced Practitioner, with people with learning disabilities. This was acknowledged by the Chief Social Worker for Adults in England when she launched phase 2 stating her 'priority for this second phase is to really develop 'good social work' and be ambitious about what this good mean' (Romeo 2017). By nature, this insight reflects a conceptual challenge which resides within adult social work practice. Since the early 1990s community care reforms models of adult social work practice has been defined by care management, models which remain valued by health led multi-disciplinary teams (Lymbery 1998). The role of assessor and broker of services bestowed upon social workers practicing in adults and reemphasised in the implementation of the personalisation agenda (HM Government 2007) is well established as a practice norm. As Bogg argues (2008), the social worker as care manager role is clearly understood and valued by health colleagues within integrated care arrangements. The model of practice emerging from the pilot is however one of social workers who are in transition towards a less bounded space of relational practice.

\section{Critical Reflection on the Initial Insights from Phase 1 of the Named Social Worker Pilot}


The pilot is adding the existing body of knowledge which challenges traditional care management roles within social work practice in the field of learning disabilities and more widely in adult social care. People with learning disabilities experience significantly reduced opportunities to connect with others (Hatton et al 2016), and over-emphasis by professionals on the level of risk posed to themselves and others by their lifestyle choices. Such casual attributions of risk are strongly associated with power and control. Better social work, which upholds people's right not to experience disproportionality of response to ordinary levels of risk taking may significantly impact on better lifetime outcomes for people with learning disabilities (James et al 2017). However, the emerging picture from the pilot, which was also as observed within the original Individual Budget Pilots (Manthorpe 2009), is that transactional approaches towards supporting people with learning disabilities may remain pervasive, as contrasted with relational practices that value people (SCIE 2016, 2017a, 2017b, James et al 2017). Care management continues to reinforce traditional power asymmetries and ultimately increase the risk of institutional abuse associated with 'bureaucratization' of relationships between people (Graeber 2015; Hatton 2-15).

As the pilot moves into the second phase, the themes which are emerging in the sites we are supporting are those of transitions and change. Periods of transition represent pivotal moments in the lives of people with learning disabilities, where professional practice and service provision frequently fail to put the good life envisaged by learning disability policy and by people with learning disabilities and their families at the heart of decision-making (Brown et al 2017). In phase 2, we are exploring how Named Social Workers may act as coordinating agents within the system, and to what extent social work is an influencing factor on how open the 
system is to enable people with learning disabilities and their families to hold it into account for the lifetime outcomes they experience. During phase one, the [site] Named Social Workers were champions for social work models which emphasised relational practice and explicitly recognised strengths and power asymmetries. During phase 2, we are also exploring the effect of involving selfadvocates in the development of post-qualifying education for social workers on the extent to which they are either open or resistant to integrating new learning and insights with their existing tacit understanding of their role.

The change literature highlights the extent to which individuals can become highly skilled at defending their tacit assumptions through development of defensive cognitive routines which become the origin of resistance to adaptation when the environment evolves requiring changes of them (Schein 1990). When faced with the ontological threat posed by new thresholds they resist the liminal space that is opening up before them because they 'see where the threshold is leading and ...become resistant to it' (Morgan 2012:221) Argyris (1990) proposed resistance becomes harder to address over time as individuals evolve defensive routines into skilled incompetence to protect their existing tacit knowledge becoming what Cousin (2006) would term 'defended' practitioners who will construct 'conditions of safety' within with to operate Morgan (2012) observes that social worker students and practitioners can develop skilled resistance routines through their 'mimicking' of new expectations without having passed the threshold values shift required to fully integrate their new understanding of their role. de Jager (2001) argues that resistance to change is generated by the 'suspicion' people feel about moving to the 'unfamiliar' future, rather than necessarily being resistance to the 
values underpinning the change itself. Phase 2 of the pilot is providing the opportunity for deeper generative learning relating to this phase 1 insight. Applying a disability studies perspective (Morgan and Roulstone 2012), there is a more critical argument about the purpose of social work with adults being examined during phase 2 of the pilot. Consideration is being given to what it means to work in a cooperative space with adults with learning disabilities who are supported by user-led organisations to contribute their expert by experience view on the role and purpose of social work in their lives. Themes of coproduction run through the social work education literature, with arguments, made that a reframed social work role, freed from the industrialised concerns of a traditional care management approaches, could achieve emancipatory ambitions for people who experience social work support (Beresford and Croft 2004). The particular relevance of this insight to the Named Social Worker pilot is that self-advocates with learning disabilities experience particular barriers to access when compared with other self-advocacy cohorts (Harkes, Brown \& Horsburgh 2013). A number of sites explored working cooperatively with people with lived experience of social work about what it means to work with people in holistic and genuinely personcentred ways during the pilot including:

having experts by experience as paid team members to help shape the learning disabilities social work service;

making every interaction - from a phone call to an assessment - as meaningful as possible;

shifting the emphasis to when an individual requests support from their social worker, rather than presume the level of interaction they require (SCIE 2017a). 
The evaluation of the two pilot sites which are reported in this paper included a practitioner conference which was held at Lancaster University to mark the launch of phase 2, attended by both self-advocates and social workers. The conference considered what factors contribute towards and have the potential to hinder better social work practice in supporting adults with learning disabilities. A subsequent focus group has taken place with self-advocates, who were supported by the user-led organisation Bradford Talking Media, to move into a deeper iterative cycle of exploration of what outcomes people with learning disabilities want for themselves and how a named social worker can contribute to this. Both Local Authorities involved in the pilots which are the subject of this paper used pilot funding to enable the self-advocacy organisations Bradford Talking Media and Lead the Way to engage self-advocates to develop their own thinking about the role of social workers and to engage in a critical dialogue with social workers from the local authority to question and challenge assumptions and practice. Themes of humanity, inherent dignity and upholding of rights are emerging from coproduction work with self-advocates. These themes reflect arguments made by Beresford et al. (2007) who call for greater emphasis on humanity in relationships between social workers and people who they support including listening, empathy, warmth and embracing of 'friendship' as core to the relational basis for interactions.

The emerging insights from our engagement with user-led organisations, which we are continuing to explore in greater depth during phase 2 , raise questions about how post-qualifying education support social workers in making the paradigm shift towards a rights-based relational model of practice. Such an approach moves beyond social workers seeking the answer to the question - how do you want me in your life - to defining their practice with the question - do you want me in your life 
at all? and if so, for what purpose? This is a particularly troubling concept for many social workers as it challenges the long held professionally 'taken-forgranted assumption' that professional practice is by its nature 'helpful' (Morgan 2012). By selecting adults with learning disabilities as the loci of the first pilot for this redefined social work role, the pilot has thrown into sharp relief the everyday experiences of people whose lives are contested spaces within which professionally dominated lens of risk turns every action into a continual struggle for autonomy and control. In this space, social workers skilled in relational approaches and educated in the social model of disability, with its theoretical underpinnings in disability studies, may hold promise to be able challenge deep held values and assumptions and achieve better outcomes (James et al 2017).

\section{Concluding Reflection}

The purpose of this paper was to draw on our experience from contributing to the learning being generated from Local Authority sites involved in the Department of Health Named Social Worker pilot. We also sought to stimulate debate to further the generative learning from the pilots and contribute towards a deeper understanding of knowledge and skills to be supported by social work education which promotes effective social work practice in the field of learning disabilities. Through the pilot we continue to examine the role of post-qualifying social work education as a factor in influencing the extent to which practitioners maintain their reflexivity and are able to continually self-reflect and examine how coherent their current practice is with their social work values. We are also beginning to consider influencing factors which effect how experienced social workers move between existing states and emerging models of practice. Our early findings 
suggest that the intersect between disability studies, with its emphasis on human rights and the agency of self-advocates, may provide a helpful frame within which to position the findings from the pilot for social work post-qualification practice to enhance advanced social work practice in the field of learning disabilities.

\section{Funding}

This work was supported by the Department of Health under the Named Social Worker pilot grant. The views of the authors do not necessarily those of the commissioners.

References

Adams, R., Dominelli, L. \& Payne, M. (2009). Practising Social Work in a Complex World. Second Edition. New York. Palgrave Macmillan.

Argyris, C. (1990). Overcoming Organisational Defences: Facilitating Organisational Learning. USA. Allyn and Bacon.

British Association of Social Workers (BASW) and Shaping Our Lives (2016) Disabled adults and social workers: Position Statement London. BASW and Shaping Our Lives Available at https://www.basw.co.uk/resources/disabled-adults-and-socialworkers-position-statement Last accessed 10th July 2018

Beresford, P. (2007) The Changing Roles and Tasks of Social Work From Service Users' Perspectives: A literature informed discussion paper. London: Shaping Our Lives

Beresford, P and Boxall, K. (2012) Service Users, Social Work Education and Knowledge for Social Work Practice. Social Work Education 31 (2) pp.155-167. 
Beresford, P. and Croft, S. (2004) Service Users and Practitioners Reunited: The Key Component for Social Work Reform. The British Journal of Social Work, 34 (1) pp. 53-68

Beresford, P., Croft, S. and Adshead, L. (2007) 'We Don't See Her as a Social Worker': A Service User Case Study of the Importance of the Social Worker's Relationship and Humanity. The British Journal of Social Work, 38 (7) pp. 13881407

Bogg, D. (2008). The Integration of Mental Health Social Work and the NHS. Learning Matters. Exeter

Broadhurst, K., Hall, C., Wastell, D., White, S. and Pithouse, A. (2010). Risk, Instrumentalism and the Humane Project in Social Work: Identifying the Informal Logics of Risk Management in Children's Statutory Services. The British Journal of Social Work, 40 (4) pp. 1046-1064.

Brown, M. James, E. and Hatton, C. (2017) A Trade in People: The inpatient healthcare economy for people with learning disabilities and/or Autism Spectrum Disorder. Lancaster: Centre for Disability Research. [Online]. Available at http://wp.lancs.ac.uk/cedr/files/2017/06/A-Trade-in-People-CeDR-2017-1.pdf Last accessed 28 July 2018.

Cousin, G. (2006). “Threshold concepts, troublesome knowledge and emotional capital: an exploration into learning about others". In Overcoming Barriers to Student Understanding: Threshold Concepts and Troublesome Knowledge, Edited by: Meyer, J. H. F. and Land, R. London \& New York: Routledge. 
Department of Health (1971) Better Services for the Mentally Handicapped.

London: Her Majesty's Stationery Office. [Online]. Available at:

http://navigator.health.org.uk/content/better-services-mentally-handicappedwhite-paper-was-published-department-health-june-1971 Last accessed 10 August 2017.

Department of Health (2001) Valuing People A New Strategy for Learning Disability for the $21^{\text {st }}$ Century [Online] Available at https://www.gov.uk/government/uploads/system/uploads/attachment_data/file/ 250877/5086.pdf

Department of Health (2007) Valuing People Now: a new three-year strategy for people learning disabilities ‘Making it Happen’ [Online] Available at:

http://webarchive.nationalarchives.gov.uk/20130105064234/http://www.dh.gov. uk/prod_consum_dh/groups/dh_digitalassets/documents/digitalasset/dh_093375.p $\underline{\mathrm{df}}$ Department of Health (2010). Building a Safe and Confident Future: Detailed Proposals from the Social Work Reform Board. [Online]. Available at: https: / / www.gov.uk/government/publications/building-a-safe-and-confidentfuture-detailed-proposals-from-the-social-work-reform-board Last accessed 10 August 2017.

Department of Health (2015). No voice unheard, no right ignored - a consultation for people with learning disabilities, autism and mental health conditions. [Online]. Available at:

https://www.gov.uk/government/uploads/system/uploads/attachment_data/file/ 409816/Document.pdf Last accessed 10 August 2017. 
Department of Health (2016). Vision for adult social work. [Online]. Available at: https://www.gov.uk/government/publications/vision-for-adult-social-work-inengland Last accessed 10 August 2017. de Jager, P. (2001). Resistance to Change: A New View of an Old Problem. The Futurist. 35 (3) pp. 24-27.

Economic and Social Research Council (2015). ESRC Framework for Research Ethics: Updated January 2015. [Online]. Available at http:/ / www.esrc.ac.uk/files/funding/guidance-for-applicants/esrc-framework-forresearch-ethics-2015/ Last accessed 20 July 2018.

Fenton, J. (2016) Values in social work: reconnecting with social justice. Basingstoke: Palgrave Macmillan

Flynn, M. (2012). South Gloucestershire Safeguarding Adults Board: Winterbourne View Hospital a Serious Case Review. [Online]. Available at: http://hosted.southglos.gov.uk/wv/report.pdf Last accessed 10 August 2017. Goodley, D. and Runswick-Cole, K. (2014). Becoming dis/human: Thinking about the human through disability. Discourse: Studies in the Cultural Politics of Education. DOI: 10.1080/01596306.2014.930021

Graeber, D. (2015). The Utopia of Rules: On Technology, Stupidity, and the Secret Joys of Bureaucracy. First Meville House Printing

Gray, D E (2004). Doing Research in the Real World. Second Edition 2009. London. SAGE Publications Limited.

HM Government (2007) Putting people first: A shared vision and commitment to the transformation of adult social care, London: HM Government. 
Harkes, M. A., Brown, M. \& Horsburgh, D. (2013), 'Self-Directed Support and People with Learning Disabilities: A Review of the Published Research Evidence', British Journal of Learning Disabilities, 42(2), pp. 87-101.

Harvey, M. (2014) Where were all the social workers? [Online]. Available at https: / / mwharveyblog.wordpress.com/2014/09/22/where-were-all-the-socialworkers/ Last accessed 06 November 2017.

Hatton, C. (2015) The four staplers of the apocalypse: Bureaucracy and people with learning disabilities [Online]. Available at:

http://chrishatton.blogspot.co.uk/2015/04/the-four-staplers-of-apocalypse.html

Hatton C., Glover G., Emerson E., and Brown I. (2016). People with Learning Disabilities in England 2015. Public Health England, London.

James, E. and Mitchell, R. (2017a). To AMHP or not to AMHP. [Online]. Available at https: / / lastquangoinhalifax.wordpress.com/2016/10/08/to-amhp-or-not-to-amhp7daysofaction/ Last accessed 20 July 2018.

James, E., Morgan, H. and Mitchell, R. (2017b). Named social workers - better social work for people with learning disabilities? Disability and Society. 32 (10) pp. 1650-1655.

Joint University Council (2016). Social Work Education Committee Code of Ethics for Social Work and Social Care Research. [Online]. Available at http://www.juc.ac.uk/swec-research-code.html Last accessed 20 July 2018.

Kemmis, S. (2008). 'Critical Theory and Participatory Action Research'. In P Reason \& H Bradbury (Eds). Handbook of Action Research: Participative Inquiry and Practice. London. SAGE Publications Limited. 
Lipsky, M. (1980). Street-level bureaucracy: Dilemmas of the individual in public services. Russell Sage Foundation. London.

London Borough of Hillingdon v Neary and Anor [2011] EWCOP 1377 (2011).

[Online]. Available at:

http://www.bailii.org/ew/cases/EWHC/COP/2011/1377.html Last accessed 05 September 2017.

Lymbery, M. (1998). Care Management and Professional Autonomy: The Impact of Community Care Legislation on Social Work with Older People. The British Journal of Social Work 28, 836-878

Manthorpe, J., Jacobs, S., Rapaprt, J., Challis, D., Netten, A., Glendinning, C., Stevens, M., Wilberforce, M., Knapp, M. \& Harris, J. (2009). Training for Change: Early Days of Individual Budgets and the Implications for Social Work and Care Management Practice: A Qualitative Study of the Views of Trainers. The British Journal of Social Work. 39 (7) 1291-1305.

Meyer, J. \& Land, R. (2003). Threshold Concepts and Troublesome Knowledge: Linkages to Ways of Thinking and Practising within the Disciplines, Enhancing Teaching-Learning Environments in Undergraduate Courses Project Occasional Report 4 [online]. Available at:

http://www.etl.tla.ed.ac.uk//docs/ETLreport4.pdf Last accessed 20 November 2017.

Morgan, H. (2012). The Social Model of Disability as a Threshold Concept:

Troublesome Knowledge and Liminal Spaces in Social Work Education. Social Work Education. 31 (2) pp. 215-226 
Morgan, H. and Roulstone, A. (2012) Editorial: Special Issue Disability Studies and Social Work Education in Social Work Education. 31 (2) pp. 137-141

Moriarty, J. \& Manthorpe, J. (2013). Shared Expectations? Reforming the Social Work Qualifying Curriculum in England. 32 (7) pp. 841-853.

NHS Southern Health (2016). Trust Statement Regarding Connor Sparrowhawk's Death. [Online]. Available at:

http://www.southernhealth.nhs.uk/news/archive/2016/trust-statementregarding-connor-sparrowhawks-death/ Last accessed 11 October 2017.

Romeo, L. (2016) Citizenship and rights. In praise of 'named social worker' pilots. [Online]. Available at: https://lynromeo.blog.gov.uk/2016/07/13/citizenship-andrights/ Last accessed 05 October 2017.

Romeo, L. (2017). Named Social Worker Pilot - the sequel. [Online]. Available at: https: / /lynromeo.blog.gov.uk/2017/10/19/named-social-worker-pilots-thesequel/ Last accessed 06 November 2017.

Romeo, L. (2018). Lessons learned from the named social worker programme. [Online]. Available at https://lynromeo.blog.gov.uk/2018/07/24/lessons-learnedfrom-the-named-social-worker-programme/ Last accessed 28 July 2018.

Ryan, S. (2017). Justice for Laughing Boy Connor Sparrowhawk - A Death by Indifference London: Jessica Kingsley Publishers

Schein, E. H. (1990). Organisational Culture. American Psychologist. 45 (2) 109119. 
SCIE (2016). Department of Health Named Social Worker Baseline Report. [Online] Available at: https://www.scie.org.uk/social-work/named-social-worker Last accessed 30 December 2017.

SCIE (2017a). Department of Health Named Social Worker Learning Report. [Online] Available at: https://www.scie.org.uk/social-work/named-social-worker Last accessed 30 December 2017.

SCIE (2017b). Named Social Worker: Findings from the Six Sites. [Online]. Available at: https://www.scie.org.uk/social-work/named-social-worker Last accessed 30 December 2017.

SCEI (2018). Putting people at the heart of social work: lessons from the named social worker programme. [Online]. Available at https: / /www.innovationunit.org/wp-content/uploads/Putting-people-back-at-theheart-of-social-work-lessons-from-the-Named-Social-Worker-programme-1.pdf Last accessed 20 July 2018.

Shaw, I., Lunt, N. \& Mitchell, F. (2014). Practitioner Research in Social Care: A Review and Recommendations. National Institute for Health Research. London. Strategic Learning and Research Advisory Group for Health and Social Care (StLaR) (2002/2003). [Online] Available at:

http://webarchive.nationalarchives.gov.uk/20031220225325tf_/http://www.dfes. gov.uk/stlar/ Last accessed 17 September 2017.

The College of Social Work (TCSW) (2012). The Professional Capabilities Framework. [Online]. Available at: http://www.tcsw.org.uk/pcf.aspx Last accessed 17 September 2017. 
Warner, J. \& Sharland, E. (2010). Editorial. The British Journal of Social Work. 40 (4) pp. 1035-1045. 